\title{
THE ROLE OF THE NATURAL LAW IN THE FRENCH SECOND COLONIAL EMPIRE. THE EXAMPLE OF THE FRENCH COLONIAL LAW IN ALGERIA (1830-1930)
}

\begin{tabular}{lr} 
DOI: & $10.24193 / S U B B i u r .65(2020) .3 .5$ \\
Data publicării online: & 09.03 .2021 \\
\hline
\end{tabular}

Amar LAIDANI*

\begin{abstract}
The article examines the role played by the natural law in the History of French colonial law during the Second French colonial Empire. We analyse how the notion of the natural law, which was perceived as an instrument of emancipation during the French Revolution, became an instrument of legal acculturation in the French colonial law in Algeria. We focus the attention on the case of Algeria during the period 1830-1930, for the reason that in this colony, the French tried to apply a policy of legal assimilation that tried to modify the Muslim law and the Kabyle customary law, making them more similar to the French law. The natural law had an important role in three phenomena: the implantation of private property, the codification of the Kabyles' customs and the Muslim Law and the reformation of the customary law in the matters of inheritance and marriage. Customary law.

Keywords: Natural Law, Colonial Law, Legal acculturation, Codification,
\end{abstract}

* Ph.D. in legal history obtained at the Faculty of law of the University of Montpellier (France) in cotutelle with Laval University (Canada). 


\section{LE RÔLE JOUÉ PAR LE DROIT NATUREL PENDANT LE SECOND EMPIRE COLONIAL FRANÇAIS. L'EXEMPLE D'ALGÉRIE PENDANT 1830-1930}

Résumé : L'article examine le rôle joué par le droit naturel dans l'histoire du droit colonial français pendant le Second Empire colonial français. Nous avons analysé comment la notion de droit naturel qui, pendant la Révolution française était perçue comme instrument d'émancipation, devint à partir du XIXe siècle un instrument d'acculturation juridique par le droit colonial français en Algérie. Nous avons porté notre attention sur le cas de l'Algérie au cours de la période 1830-1930, cela pour la raison que dans cette colonie les Français ont essayé d'appliquer une politique d'assimilation légale qui a essayé de modifier la loi musulmane et la coutume kabyle en les rapprochant à la loi française. La loi naturelle a joué un rôle important dans trois phénomènes distincts du droit colonial français en Algérie: l'implantation de la propriété privée, la codification des coutumes kabyles et du droit musulman et la réforme du droit coutumier en matière d'héritage et de mariage.

Mots clés : Droit naturel, Droit colonial, Acculturation colonial, codification, droit coutumier. 
Table of Contents

I. Introduction 143

II. The role played by the natural law in the French Legal colonial History of the Ancient Regime 145

A. The natural law Theories and the Europeans conquest of the $16^{\text {th }}-18^{\text {th }}$ centuries

B. The natural law theory and the French Law durint the Ancient Régime....... 148

III. The role of the natural law in the French's colonial rule in Algeria ....................... 157

A. The implantation of private property in the colonies ................................... 157

B. The codification of the Muslim law and the customary law in Algeria.......... 164

C. The reformation of the Muslim law and the customary law .......................... 169

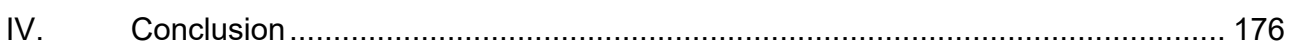

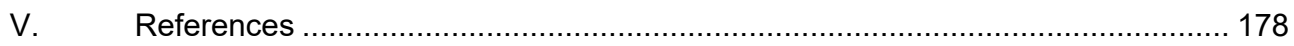

I. Introduction

The notion of modern natural law is rooted in European colonial history. The modern natural law theory was developed by the Spaniard scholars of Salamanca and by protestant jurists such as Grotius, Pufendorf and Wolf, from the $16^{\text {th }}$ until the $17^{\text {th }}$ centuries, to legitimate the colonial conquests of their countries in the New World.

The concept of modern natural law appears in France only after the 17 th century. Before the French revolution, the French jurists Domat and Pothier used the natural law predominantly only for domestic French law question. 
After the $18^{\text {th }}$ century, the notion of natural law was mentioned in reference to the colonial questions by the Enlightenment philosophers and the Physiocrat economists. The Universal Declaration of the Rights of Man and of the Citizen of 1789 was the consecration of the natural law theories. During the French Revolution, the natural law concept was used as an antislavery and an anticolonial argument. However, after the Napoleon Campaign in Egypt of 1797, the natural law was employed as a rhetorical tool for legitimising the colonial conquest and the indigenous populations' legal acculturation. Although the concept of the natural law appeared later in the French colonial law, concerning other European colonial powers like Spain, England and the Netherlands, this notion played a significant role in the French colonial law during the period from the $19^{\text {th }}$ century until the beginning of the $20^{\text {th }}$ century, after the conquest of Algeria in 1830. Algeria was the laboratory of French colonial law in the $19^{\text {th }}$ and $20^{\text {th }}$ centuries. The French colonial law applied in this colony was the triumph of the modern theories of natural law. In the Algerian colonial context, the natural law was identified both with the principle of human rights and with the legal rationality of the French legal tradition. In the name of such legal rationality, the French colonial administration codified in Algeria the local Muslim law. Still, in the name of the natural law, the French courts modified and reformed the indigenous population's customary law. The natural law was a tool used by the French colonial jurists to resolve the issues arising from a contrast between the local customs and the French law. In some cases, the local customs were considered as opposed to the natural law.

In our article, we will see the French colonial approach's specificities to the notion of natural law. It is necessary to understand the colonial origin 
of the modern theory of natural law and how the notion of modern natural law was rooted in French legal history (section I). In the second part of this article, we will see how the notion of natural law was used in the colonial legislation in Algeria during the Second French colonial Empire (section II). We will focus our attention on three phenomena: the implantation of private property, the codification of the customary law and the reformation of this customary law.

II. The role played by the natural law in the French Legal colonial History of the Ancient Regime

The modern natural law theory was developed during the $16^{\text {th }}$ century by the Spanish Scholastic scholars of the School of Salamanca, such as Vitoria, de Molina and Suarez and by the protestant legal philosophers such as Grotius, Pufendorf, Locke and Wolff. The Modern natural law was a secularised version of the Natural law of the Aristotelian-Thomist tradition.

For the theorists of the modern Natural law, contrarily to the AristotelianThomist tradition approach, the natural law was not obtained through the observation of nature but using deductive logic. The modern legal theorists were convinced that the natural law was rooted in the human mind's rational faculty.

\section{A. The natural law Theories and the Europeans conquest of the $16^{\text {th }}$ $-18^{\text {th }}$ centuries}

Modern natural law played an important role during the European colonial conquest of the $16^{\text {th }}$ century. The natural law was used as an argument 
to legitimate the colonial conquest and as a legal instrument for resolving the conflicts which arose between the European countries during the conquest of the American continent. The natural law was also seen as a neutral and universal system of norms that rules the relationships between the European colonists and the native Americans.

However, despite this supposed neutrality of that norms, the Natural law theorist conveyed the idea that only the Europeans were gifted of a sufficiently developed intellectual capacity and rationality that enables them to understand and define the principles of this natural law. This same rationality enables the European settlers to exploit American territories rationally. On the opposite, natural law scholars supported the idea that the cultural specificities of the Native Americans make them inept at understanding and applying the principles of natural law. This kind of argument was used by the Spanish priest and humanist Sepulveda for legitimising the institute of the encomienda in their colonies, claiming that the customary law of the Indians violated the Natural law ${ }^{1}$. Contrarily to Sepulveda, the Dominican priest Francisco Vitoria supported the idea that, although native Americans were not able by their own to understand "entirely the natural $\mathrm{law}^{2}$, they were gifted of reasoning capacity and recognised that their political organisation had reached a certain level of rationality ${ }^{3}$.

\footnotetext{
${ }^{1}$ J. G. DE SEPÚlvedA, Democrates secundum (1535), Madrid, éd. A. Losada, 1951, p. 37. Cited in G. Demelemestre, « Les Dominicains et les Indiens » in Clio thémis n. 16, 2019, p. 17.

2 F. DE Vitoria, Leçon sur les Indiens, p. 75, Cited in G. Demelemestre op. cit.p. 9. 3 Ibid.
} 
Similar arguments were employed by the British in their North American colonies, such as Locke, who used the natural law for legitimising and defending the English colonisation of North America with regard to the other European powers as Spain and the native Indian. Locke advocated the idea that it was necessary for the British to exploit the properties in North America, adopting the labour and settlement. Locke claimed in the Second treaties of government that the native Americans were not able to exploit their lands for the reasons that they:" [. . .] don't have fences or boundaries, and are still joint tenants of their territory · but if any one of them is to get any benefit from fruit or venison, the food in question must be his-and his (i.e. a part of him) in such a way" (VI, 26).

However, this Eurocentric vision was not shared by some theorists of the natural law as Grotius, Pufendorf and Thomasius. As Tourme-Jouannet explained, jurists tried to identify the principle of natural law in an abstract and neutral rationality and not in an arbitrary legislation of the European countries ${ }^{4}$. One of the reasons was mainly the fact that during the $16^{\text {th }}-18^{\text {th }}$ centuries, Europe was crossed by violent wars and, consequently, the European people's law (ius gentium) was not considered as an element that should be imported into the New World and imposed to the native Americans ${ }^{5}$. The natural law treatises of the $18^{\text {th }}$ century dedicated few pages to the question of the native populations. Sometimes the Indians customs were described as more advanced than the European countries laws. For

4 E. Tourme-Jounnnet, « Des origines coloniales du droit international », in The Roots of International Law. Les fondements du droit international, Leiden, Boston, Nijhoff publishers, p. $657-658$.

5 Ibid., p. 658. 
example, Thomasius claimed in 1705 that the customs of the "so-called" civilised countries could be crueller than those of the "barbarian nations" Montesquieu wrote in the Spirits of Law that the Indians Cherokee had a real right of people ${ }^{7}$, observing that the Cherokee sent ambassadors and had rights of war and peace, the fact of eating their prisoners did not matter ${ }^{8}$.

This attitude changed during the $19^{\text {th }}$ century since the notion of natural was identified by the French colonial jurists with the principle of the European tradition. As we will see below, the French colonial jurists will use the notion of the natural law as an instrument of the acculturation of the indigenous populations of their colonies.

\section{B. The natural law theory and the French Law durint the Ancient Régime}

The notion of natural law was rarely evoked in French colonial law before the $17^{\text {th }}$ century. The issue of natural law in the colonies had been faced only during the French revolution. Indeed, the modern natural law theories appeared in France only during the $17^{\text {th }}$ century through the works of the French Protestant jurist Barbeyrac who translated and commented on Locke, Grotius and Pufendorf during the period 1706-1727. The natural law theory was popularised in France also by the work of the Swiss jurist Burlamaqui who wrote in the French language his major opera, titled Principe du droit naturel (1747).

${ }^{6}$ Ibid.

7 Montesquieu, De l'esprit des lois, tome I, Garnier Frères, Paris, 1961, p. 9.

8 Ibid., p. 9. 
The Modern natural law theories were criticised during the Ancient Régime by the Jansenist philosopher Blaise Pascal (Pensées, $n$. 33o) and by the Enlightenment era philosophers like Rousseau and Voltaire. The latter, while vigorously attacking the hopefulness of Leibniz and Wolff in his philosophical novel titled Candid, advocated at the same time the idea of the natural law based on scepticism, as theorised by John Locke. Voltaire, in his treaty titled Traité sur la tolérance claimed that the human laws must comply with the principle of the Natural law (VI). Rousseau, although he condemned in his opera titled Le contrat social the idea of sovereignty supported by Grotius, still used the concept of natural law in his theory of the social contract and advocated in his works the idea of the existence of a natural law which was present in all human societies as in the social contract. As Amselle explained, Rousseau wanted to "[...] bring natural law to the fore in civil status present in the state of nature and which has been perpetuated in a new form in the emerging society ${ }^{9} \gg . "$

Since the $17^{\text {th }}$ century, modern natural law played an essential role in the French legal, political and economic theories. This influence was strong in the work of the French jurist Domat, titled Les loix civiles dans leur ordre naturel. He advocated that a certain number of legal principles were deeply rooted in Roman law and in the natural law as the modern natural law scholars like Grotius, Leibniz, Wolff, and Domat believed that positive laws should be inspired by the natural law, which was a reflex of a common rationality rooted in the natural order.

9 J.-L. AMSELle, Vers un multiculturalisme français, Champs, Flammarion, Paris, 1996.,p. 32. 
Domat conceived the science of law as a rational science that can be determined with the same inductive-deductive logic of the scientific science as geometry. For this reason, the French jurists exposed in their treaties the legal institutes using the style of the treaties of geometry and so using the following order: definition, principle and demonstration. This geometrical scheme used by Domat influenced the work of his scholar, Pothier. The latter was a French lawyer who made a commentary on the customary law of the city of Orleans, in which he used the same geometrical scheme adopted by Domat. However, the commentary of Pothier presented some elements of originality. At the time of Pothier, the European legal tradition was crossed by two different methodologies. The first one was the approach adopted by the commentators of the customary law who used the interpretation methodology. On the opposite, there was the approach of the natural law theorists who used a methodology based on the demonstration. On the other hand, Pothier adopted an original approach that was a third way between the Commentators and the Natural law scholars' approach and has interpreted and commented on the customs of Orleans in view of obtaining the common principle of the above customs. According to Pothier, the laws were not the result of the social relationships but only a product of the principles of the science of law ${ }^{10}$.

Domat and Pothier paid no attention to the colonial problems and the slavery question in the French colonies. Domat, in the part of his treatise dedicated to the institute of slavery, did not dedicate any issue to the question

\footnotetext{
10 D. Deroussin, « Pothier, la coutume (d'Orléans) et le droit coutumier », in F. GARnier, G. CAZALS, Les décisionnaires et le coutume, Contribution à la fabrique de la norme, Toulouse, $\mathrm{P}: \mathrm{U}$ : Toulouse 1, 2018, p. 440.
} 
of the slavery practised by the French in their overseas colonies. Pothier, on the other hand, dedicated few words to the question of slavery in his Traité des personnes et des choses in which, by the way, he advised the slave owners about how they can avoid the loss of their slaves in the case they decide to travel with them in France ${ }^{11}$.

During the $18^{\text {th }}$ century, the concepts of natural law played an essential role in the works of the French physiocrats economists like Quesnay. At the same time, the notion of natural law influenced the work of the philosopher Montesquieu. In chapters 2 and 3 of his fundamental treaties titled $D e$ l'Esprit des Lois, the French philosopher introduced a dichotomy between the natural law and the positive law.

Contrarily to what happened with Domat and Pothier, after the $18^{\text {th }}$ century, the French natural law theorists began to develop a critical stance towards French colonisation. Natural law was used to criticise how France ruled their colonies during the period of the Ancient Régime. These critics were directed to the mercantilist colonial policy and the practice of slavery. During the 1750s, the Physiocrats economists criticised the mercantilist colonial system adopted by the French Indian Company and advocated adopting a more liberal policy in the colonies. The enlightenment era philosophers, from their side, were also very critical towards colonisation and slavery. In his work, titled l'Ami de l'homme, Mirabeau was radically critical toward modern colonialism and how the European powers colonised the New

\footnotetext{
11 R.-J. Pothier, Traité des personnes et des choses, in De M. Dupin, Euvres de Pothier contenant les traités du droit français, Paris, Pichon-Becher, 1827, p. 21.
} 
World since $1492^{12}$. However, during the $18^{\text {th }}$ century, the Physiocrat economist Quesnay and the philosopher Mirabeau denounced the stark contrast between the principle of the natural law and the slavery practised by the French in the colonies. They wrote together a treaty in which they claimed that the slavery practised by the French in the colonies was a perversion of the natural order ${ }^{13}$.

This idea was shared with Montesquieu, who, in his treatises titled $D e$ l'Ésprit des Lois, wrote that slavery was opposed to civil law and was a violation of the natural law ${ }^{14}$. The same idea was supported by other enlightenment era philosophers, such as Condorcet, who wrote in his treaties that slavery could be in any case legitimated by the natural law theory ${ }^{15}$, and he concluded that for not any reason, any human being could not be private from his natural rights ${ }^{16}$. Condorcet also claimed that the slaves should obtain compensation from their ancient masters because slavery was a crime in the name of the natural law ${ }^{17}$

The French revolution stated the triumph of the rational current of the natural law inside the French Law. The Declarations of the Rights of the Man and of the Citizen of 1789 and 1793 were based on the natural law concept as well, which was conceived as a common heritage belonging to humanity. As

\footnotetext{
12 Mirabeau (V. Riqueti, marquis de),, L'ami de l'homme ou Traité de la Population, Vol. III, ch. VI p. 203-204.

13 Mirabeau (V. Riqueti, marquis de), QueSnaY F., Philosophie rurale ou Economie générale et politique de l'Agriculture, Les Libraires associés, Amsterdam, 1763, p. 49.

14 Ibid.

15 N. DE CONDORCET, Réflections sur l'esclavage des nègres, Neufchatel, 1781, p. 14.

${ }^{16}$ Ibid., p. 15 .

17 Ibid., p. 17.
} 
known, the revolutionaries were deeply influenced by the Enlightenment philosophy. For that reason, they claimed that the concept of the natural law consecrated in the Declaration of 1789 was incompatible with the colonial conquest and the practice of slavery, which was still in use in the French colonies during the years of the French revolution.

The Jacobins' ideology was deeply opposed to the colonial conquests. Robespierre believed that the "right of conquest" advocated by the European colonial theorists was incompatible with the principles of the civil and international law declared by the Constituent Assembly. On May $16^{\text {th }}, 1790$, the deputy Jallet claimed that the war of conquest was opposite to the principle of natural rights and claimed that: "Any unjust aggression is contrary to natural law ${ }^{18 “}$. As we said above, the Jacobins were opposite to slavery. Robespierre claimed that: "The Declaration of the rights of the man and the citizen" of 1789 was the constitution of all the people. This means that this right defended in this declaration was also recognised to the indigenous population in the colonies and to those who were reduced in a regime of slavery.

However, and at the same time, the colonial lobby represented by deputies like Moreau, Maurry and Mallouet was opposed to the application of the Declaration of 1789 in the colonies. These deputies also advocated the necessity of the maintenance of slavery. Through the debate held at the constituent assembly that took place from May to September 1791, Mallouet emitted the idea that natural law and the Universal Declaration of Human Rights should not be applied in the French colonies. This colonial current

18 F. GAUTHIER, Triomphe et mort du droit naturel en Révolution 1785-1795-18o2, Pratiques Théorique, Paris, Puf, 1992. p. 130. 
influenced the French Constitution of 1793, which marked a first break between the universalist ideal of human rights and the natural law of the French revolution. Moreover, the influence of the colonial lobby was more marked in the Constitution of 1795 , which has no reference to the idea of a natural law conceived as a heritage common to the whole of humanity. The natural law was replaced by a reference to man's "rights and duties in society".

The notion of Natural law exerted a strong influence also on the redaction of the Napoleon Civil code. One of the coders, Portalis, in Discours préliminaire sur le Code civil defined the natural law as a dateless common law, present in every country ${ }^{19}$. Portalis also defined the notion of the people's right (droit des gens) as the common reason that rules relationships between the different populations ${ }^{20}$. The differences between the notion of the natural law and the peoples' rights were not in their substance, but only in their application, so natural law was applied everywhere and every time, the peoples right was applied only in the international agreements which regulate the relationships between the countries ${ }^{21}$. Therefore, the natural law was a set of eternal principles untied by the wills of the peoples, and the peoples' law includes the treaties, the capitulations and the customary law ${ }^{22}$.

During the Napoleon era, this notion of Natural law was exploited for legitimising the colonial conquest. Florence Gauthier explained that this use of natural law was a direct consequence of the degradation of the natural law

\footnotetext{
19 J-É. PorTalis, Discours préliminaire du premier projet de Code civil, Préface de Michel Massenet, Collection «Voie de la cité », Editions confluences, Bordeaux, 2004, p. 81.

20 Ibid, p. 24.

${ }^{21}$ Ibid.

22 Ibid.
} 
principle experienced during the French Revolution. The Natural law was used during the French Campaign of 1797 in Egypt by the French orientalist Volney as a colonial argument. Volney was the mastermind of the Egyptian Campaign and, at the same time, the theorist of a "republican imperialism" based on the theory of natural law. The latter proclaimed in 1791 in his work entitled "Les Ruines ou Méditation sur les révolutions des empires (1791) the following:

"O kings and priests you can suspend the solemn publication of the laws of nature for a while, but it is not in your power to destroy them or overthrow them [...] Look for laws that nature has laid down for you direct, and draw up the authentic and immutable Code; but may it not be for everyone without exception! Be the legislator of all mankind, so that you will be the interpreter of the same nature; show us the line that separates the world of chimeras from that of realities, and teach us, after so many religions and errors, the religion of evidence and truth"23.

This declaration marked a turning point in the history of the French colonial Law, which became an instrument of acculturation of the indigenous population. The French legal tradition was perceived as the reflex of a common reason, susceptible to being imposed on the colonies' indigenous people. The turning point of this new colonial law happened during the beginning of the $19^{\text {th }}$ century in Senegal and Algeria. At that period, the French colonial administration tried to apply the 1804 Civil Code in the colonies. This Code was perceived as the embodiment of French legal rationality and legal civilisation, which should replace the traditional legal traditions of the

23 Volney, Les Ruines ou Méditation sur les révolutions des empires (1791), présentation de J. Thulard, Paris-Genève, Slatkine, 1979, p. 244-245. 
indigenous population who lived in French possessions in America, Africa and Asia. The decree of November $5^{\text {th }} 1830$, provided for the application of the Civil Code in the French colonies.

As Le Roy explained, the Civil Code was supposed to replace the local legal customs in the colonies, like what happened in France after the adoption of the Civil Code, where the local customs became secondary sources of law and occupied an inferior position to the principles of the French $\mathrm{Law}^{24}$.

The French legal colonial culture of the $19^{\text {th }}$ century identified the natural law with the French legal tradition and, more generally, with the European legal tradition. The legal acculturation of the indigenous populations in the French colonies was accomplished in the name of the natural law. For example, the law of April $24^{\text {th }}, 1833$ declared that it was almost against "[. . . ] humanity and natural law" to deny to the indigenous the benefit of French law". So, the natural law was employed to support the legal acculturation of the French colonies' indigenous populations.

After the conquest of Algeria in 1830, the French colonial authorities have surrendered to the impossibility to replace the Muslim and the local customary laws immediately and claimed that this legal acculturation should have to be obtained gradually. Consequently, the treaty the July $5^{\text {th }} 1830$ declared the French commitment to respect the Muslim religion and the freedom of cult, and the French authorities worked to maintain the Muslim judges.

${ }^{24}$ E. LE RoY, « La Coutumes et la réception des droits romanistes en Afrique noire », in Recueils de la société Jean Bodin pour l'histoire comparative des institutions, La coutume, volume 511990, Bruxelles, De Boeck-Wesmael, 1990, p. 127. 
III. The role of the natural law in the French's colonial rule in Algeria

Algeria was a laboratory for the French colonial law of the $19^{\text {th }}-20^{\text {th }}$ centuries. The natural law exercised its influence in three different ways. First, in the land question of the implantation of private property; second, the natural law rational ideology indirectly influenced the operation of the codification and the rationalisation of the customary law and Muslim law: finally, the natural law was used as an argument for reforming and correcting the customs that were incompatible with the French laws.

\section{A. The implantation of private property in the colonies}

The question of private property occupied a central place in the French colonial debate of the $19^{\text {th }}$ century. As seen above, private property is considered a fundamental right by the Modern natural law theory. The Scholars of the School of Natural law of Salamanca, Grotius and Locke, conveyed the idea that there was no freedom without the right of property ${ }^{25}$. Despite what happened in the other European colonial powers, before the $19^{\text {th }}$ century, few French colonial jurists wrote a complete treaty on the link between natural law and private property in the French colonies. Pothier was the first French jurist to write a complete treaty on the right of property, titled "Le Traité du droit de domaine de propriété". He traced a link between natural law and private property, but only referring to the French territory. Contrarily to the British and Dutch colonial theorists, Pothier considered the land of the native Americans as res nullius and claimed that a land inhabited

25 U. MATTEI, Senza propriétà non c'é libertà, Bari, Idola-Laterza, 2014, p.25. 
by Native Americans should be considered their property and, consequently, the seizure of that land was a violation of justice ${ }^{26}$.

The French colonial law of the Ancient regime did not adopt coherent and rational legislation regarding the acquisition of private properties in colonies. The colonial legislation of the First French colonial Empire was not focused on a unique institution of private property and admitted different kinds of ownership. As explained by de Mari, the colonial real estate policy of the Ancient regime was controlled by the French State and submitted to the national interest ${ }^{27}$. The principal legal instrument of the estate ownership was the concession ${ }^{28}$.

Algeria has been the starting point for new property legislation of the Second French colonial Empire. This legislation was influenced by the liberal ideology for which it was mandatory to declare the French State as owner of the entire colonial territory of Algeria and to establish an exclusive private property regime, a right sacred in France by article 2 of the Declaration of the Human rights as well as by the article 544 of the Civil Code.

Algeria was a laboratory for the new real estate policy. A governance of lands and tenures was applied, inspired by the colonial liberal theories in breakup with the land governance based on free concessions and adopted in

26 R-J Pothier, Traité sur différentes matières de droit civil, appliquées à l'usage du Barreau et de la jurisprudence française, tome 4, Paris, Orléans, Jean Debure/Veuve Rouzeau-Montaut, 1774, p. 375.

27 E. DE MARI, « Des devoirs du concessionnaire aux droits du propriétaire : le cas de SaintDomingue (XVIIe-XVIII siècle) », in L'empire de la propriété. L'impact environnemental de la norme en milieu contraint. Exemple de droit colonial et analogies contemporaines, Sous la direction de E. dE MARI et D. TAURISSON-MOURET, préface de Thierry Revet, Paris, Victoire Editions, 2016, p. 134

28 Ibid. 
the French colonies during the Ancient regime. In Algeria, the French authorities replaced the regime of the concessions adopted during the Ancient regime with a new one based on the auctioning of the land to the French and European settlers. That was a triumph of the liberal theses inspired by the British's legislation in Australia and New Zealand and known as the Wakefield doctrine.

The French expeditionary forces which conquered Algeria through the convention of July $5^{\text {th }}, 1830$ signed with the Turk authorities, undertook to respect: “[...] the freedom of the inhabitants of all classes [...]" and declared that: "their properties, their trade and their industry, will not receive any attack". In article 11 of the treaty of Tafna, signed in 1837, the French obtained the engagement from Algerian chief Emir Abdelkader for the respect of the properties of French and European settlers. In the proclamation of 1857 that Randon addressed to the Kabyle tribes, it was written that France would: “[...] restore order through the wisdom of command, respect for property and the maintenance of good institutions."

The French colonial land law in Algeria fixed three goals: the first one was to declare the France state owner of the entire territory of Algeria, the second one to ensure and rule the properties of the French and the Europeans settlers and the last one to make the indigenous population of Algeria with acquainted to the French notion of private property, in view of weakening the customs that hindered the instauration of private property in Algeria.

Article 4 of the law of June $16^{\text {th }}, 1851$, provided that the French state owned the property of the woods and forests of Algeria. For legitimising the domain of the French state on the Algerian territory, including the forests and the waterways, the French colonial administration and the French jurists 
argued referring not exclusively to the principle of the French and European Natural law but also the principle of Muslim public law. In view to legitimise the universal ownership of the French state over all Algerian territory, the colonial legislator had even relied on an institution of Muslim public law, the Khard thesis. The latter claimed that the Regency of Algiers was considered from the point of view of Muslim law as a land of conquest and a "land of violence" (Dar-el-Harb). This was due to the fact that before the French conquest, the territory of Algeria has been militarily conquered during the $16^{\text {th }}$ century by the Turkish army and consequently annexed to the Ottoman Empire. By means of the international Muslim law, that conquest has granted the Turks a right of ownership over all the lands under the control of the Regency of Algiers. Therefore, according to this "land of violence" theory, the indigenous Algerian tribes had no property rights in their lands but only usage rights. Consequently, according to the Khard thesis, the capitulation of the Ottoman forces to the French military forces in 1839 made the French State the new owner of all Algerian territories that were under the power of the Algiers Regency.

In fact, article 11 of the decree of 1851 specified that "[...] the property rights and the rights of use belonging to individuals, tribes and fractions of tribes [...] were recognised and maintained, regulated or constituted later by the French government. The property right consisted of the faculty of "[...] enjoying and disposing of one's property in the most absolute manner by complying with the law" (article 14). The same article declared the lands of the tribes as inalienable lands, and article 16 provided that the alienation of Muslim property between Muslims was governed by Muslim law. The Civil Code would have governed any other alienation. Thus, only the belly contracts 
between Europeans and Muslims were governed by the Civil Code. However, the legislator did not seek to replace Muslim law with French law in the transactions that took place between Muslims.

The French historian and translator Mercier testified that the French military had obtained from complacent Algerian Muslim religious authorities fake fatwas (religious advices), which legitimised the land policy desired by the French administration in Algeria. For example, in 1849 in Oran, General Charon obtained from a Muslim cadi (religious judge) a fake fatwa which was nothing else than a literal translation in Arabic of the directives of the French administration $^{29}$. This fatwa conveyed the idea that the Algerian tribes at the time of the French conquest were not the owners of the territories where they inhabit and that these tribes had at the moment of the French conquest only a simple right of usufruct. Consequently, in conformity with the Muslim public law, the military conquest of the tribal territories by France gave the French state the ownership of all the tribal territories of Algeria ${ }^{30}$.

Regarding the question of the land distribution to the French and Europeans settlers, the law of 1851 kept in place the regime of free land concessions in favour of French and European settlers. On the other hand, the defenders of liberal colonisation, such as Alexis de Tocqueville, criticised this free land concession practice. The latter was critical towards the state-run land concessions. The liberal thesis exerted an influence on the decrees of July $25^{\text {th }}, 1860$, the Senatus-consultum of 1863 and the decree of December $31^{\text {st }}$,

29 E. MERCIER, La propriété foncière chez les musulmans d'Algérie, Paris, Ernest Leroux éditeur, 1891, p. 14.

30 Ibid. 
1864. These laws eliminated the practice of the free concessions and instituted the fixed price sale contract as the only mode of alienation of state lands.

The Senatus-consultum of 1863 has limited the dimension of the common property which belongs to the Algerian tribes. The main goal was to facilitate the sale of the lands by the French and the Europeans settlers. At the same time, this legislation had as objectives to undermine the common properties and to familiarise the local population with the notion of private properties. The decree of July $26^{\text {th }}, 1873$, had imposed on the Algerian families to adopt a surname. This law aimed to weaken the local Algerian customs that impaired the free circulation of the private properties and introduce a regime of private tendering that permitted the French and Europeans settlers parts of the common properties.

The liberal theorists, as the jurist Besson and the economist Le Roy Beaulieu welcomed this solution. The latter claimed that the main goal of a colonial policy conform to the principle of the Natural law should be the question of the instauration of private property ${ }^{31}$. According to Le Roy Beaulieu, the mercantilist colonial policy of the ancient regime violated the natural law of the peoples ${ }^{32}$. So, Le Roy Beaulieu showed enthusiasm for the new regime adopted by the decrees of $1851^{33}$ and $1873^{34}$.

\footnotetext{
${ }^{31}$ M.P. LeRoy-Beaulieu, De la colonisation chez les peuples modernes, Paris, Guillaumin Libraires, 1874, p. 27.

$3^{2}$ Ibid., p. 27.

33 Ibid., p. 305.

34 Ibid., p. 328.
} 
The jurist Besson evaluated the decree of 1873 positively as he considered that this decree secured the titles of private property and weakened the indigenous customs that are contrary to private property ${ }^{35}$. At the same time, Besson proclaimed in the name of the natural law that the French legislation should allow the non-French European settlers to enjoy all the rights of property recognised to the French citizens by the French legislation $^{36}$.

The decree of 1873 was welcomed by the First minister Jules Ferry, who claimed the necessity of "[...] introducing in the Arabs world the individual property 37 " which should break "the family and the tribe ${ }^{38 \text { “. }}$

However, this decree provoked a series of abuses in Algeria. It was criticised by some opposition members, such as senator Franck Chouteau, who reported the legal acculturation during a speech in the French Assembly, affirming that it was not cautious cancelling the customs of the Muslim population of Algeria ${ }^{39}$.

35 E. BESSON, La législation civile de l’Algérie, Edition Chevalier Marescq, 1894, p. 288.

36 Ibid., p. 168

37 J. FERRY, «Premier rapport de M. Didier au nom de la commission de l'Assemblée législative », 9 juillet 1851, in E. Robe, 1854, p. 263.

$3^{8}$ Ibid.

39 A. Duparc (A.), Chronique du mouvement social, Réforme sociale, 1882, tome 1, p. 192-193 and Cazajeux (J.), Le mouvement social à l'étranger. Le Code civil et la propriété des indigènes algériens, op. cit., p. 405. 


\section{B. The codification of the Muslim law and the customary law in Algeria}

The notion of natural law influenced the phenomena of Muslim law and Kabyle's customary law codification by the French colonial authorities in Algeria during the $19^{\text {th }}$ century. The French legal tradition was used as an instrument for maintaining order and a reflex of rationality. The main goal of that codification was to submit the Algerian customs to the same rationality of the French Civil Code of 1804.

In a first step, the French authorities attempted to rationalise the Muslim law practised in Algeria by introducing a pyramidal system of Court and the codification of the Muslim law. The decree of 1 October 1854 modified the way of functioning of the Muslim jurisdiction, introducing a hierarchical system of Muslim courts called to apply the Muslim law. A system that, as explained by Bontems, was clearly inspired by the French hierarchical and both the jurisdictional system and vision of law of the Natural law theories, both of a pyramidal nature. $4^{\circ}$ Simultaneously, the French authorities sought a written source of Muslim law that, once translated in French, should be applied homogenously by the Muslim and the French courts. As underlined by Bontems, this French approach towards the sources of the Muslim law was a legacy of the modern School of the natural law, which conceived the sources of law as a hierarchical pyramid with the written sources on its top. ${ }^{41}$ Consequently, the French colonial administration ignored the oral customs

$4^{\circ} \mathrm{C}$. BonTEMS, «L'invention du droit musulman algérien à l'époque coloniale (XIX siècle). Une approche anthropologique ", in Le débat juridique au Maghreb (sous la dir. A. MAHIOU), Publisud, Iremam, 2009, p. 41.

${ }^{41}$ Ibid., p. 42. 
and worked to obtain a certain number of written sources of Muslim law. First, the French found such sources in a treaty of Muslim Law applied in Algeria before the French conquest, written in the $14^{\text {th }}$ century by a Muslim jurist, Sidi-Khalil, titled Mukhtashar. Consequently, in 1855 a translation of the Mukhtashar was published, translated in French by the orientalist Nicolas Perron.

The French administration proceeded to codify the customs of the Berber populations of Kabylia after the conquest of this territory by the French army in 1857. The Kabylia mountainous territory, inhabited by Berber spoken tribes, known as Kabyles, was the last part of northern Algeria to be colonised by the French army after a violent military campaign during 18541857, carried out by the Generals Bugeaud and Randon. In 1857, the territory of Kabylia became annexed as the rest of northern Algeria to the military regime of the Arab offices (Bureaux arabes). However, the French officers who ruled Kabylia after the conquest applied a different regime to the Kabyle population than what was applied in the rest of the Algerian colony. They chose an indirect rule form of governance with which they worked to maintain as far as possible the local political institutions and the local customs. The French militaries were convinced that the Kabyle people were less religious than the rest of the Algerian population and that their customs were less influenced by Muslim law. Therefore, the French attempted to conserve in Kabylia the local customary law, separately from the influence of the Muslim law applied in the rest of Algeria. The officers avoided the presence of Muslim judges in Kabylia.

During 1857-1871, the Kabyle population was ruled by their own customs and traditional institutions. The most important result of this interest was the codification of the Kabyles' tribal customs in a unique treaty 
entitled « The Kabylia and the kabyle customs ${ }^{42}$ ». This work was written by a military, Hanoteau, and a judge, Letourneux, after an intensive study of the Kabyles' statute and an investigation on the field in the Kabyle villages. This work was an unofficial codification of the Kabyles' customary laws, in which the latter were rationalised and made more similar to the French legal tradition. This influence was stronger in the second volume of this work, dedicated to private law. As in the old treaties of Natural law of Code, Hanoteau and Letourneux classified the Kabyle customs following the categories of Gaius, persons, obligations and goods. They classified the sources of the kabyle customs using the same plan used by the natural law treatises. Hanoteau and Letourneux similarly codified the Kabyles' customs as Pothier with the customs of Orleans.

After the success of Hanoteau's and Letourneux's work, some treatises of law appeared at the end of the $19^{\text {th }}$ century, supposed to help the French jurists apply the Muslim Law. In this frame, Seignette published Code Musulman (in 1878) and Ernest Zeys wrote a treaty titled Le droit Musulman Algérien (in 1884). At the beginning of the 2oth century, an operation of codification of the Muslim law started. This project was encouraged by the jurist Éstoublon. It was directed in 1905 by the chairman of the University of Algiers, Marcel Morand. In this project, Morand worked to find a common principle of the Algerian Muslim jurisprudence, considering not only the written sources but also the customary law. However, this project was aborted and never officialised. The Muslim authorities were opposed to this codification project that what perceived as an operation of legal acculturation.

42 A.Hanoteau, A. Letourneux, La Kabylie et les coutumes kabyles, Imprimerie impérial, trois volumes, Paris, 1873. 
As explained by Ghabrial, the main goal of the project of Morand was to "[...] aid in the "evolution" of Islamic law on its own terms, through a kind of rationalist tutelage" and to "promote an equitable Islam from early days of first caliphs, while suppressing inhumane "heretical" practices, such as could be found in regressive customary regimes 43 ."

The Algerian phenomenon of the codification of customs was subsequently exported, starting from the end of the $20^{\text {th }}$ century, to the French West Africa (A.O.F.) colonies. The Governor of Senegal and West Africa, Faidherbe, brought Senegal the institution of the undirected rule policy established in Kabylia by the Arab offices. This was due to the fact that Faidherbe had been assigned to Algeria in 1844 and 1849 for three years, to the Kabyle Campaign, under the orders of Saint Arnaud ${ }^{44}$.

As seen above, the administration of Faidherbe, based on the Directorate of Political Affairs, was inspired by the Arab Offices of Bugeaud. Faidherbe, thus, set up Koranic courts, which, according to him, aimed to protect indigenous justice from legal acculturation. Gallieni later perfected the policy of the Directorate of Political Affairs. Consequently, just as in Kabylia, the French soldiers set up an indirect administration in A.O.F., which consisted of controlling the local tribes by weakening the role of the chiefdoms and the Muslim religious authorities of the marabouts, all while maintaining in place their traditional local political institutions.

Similarly to the Arab Offices in Kabylia, the French administration in West Africa, as explained by Maupoil, had: “[...] as a principle, respect for local customs in everything they do not contradict the rules accepted by

43 Ibid.

44 J.-L. AMSELLE op. cit., p. 122. 
European civilisation ${ }^{45}$ " and the French administrators in A.O.F. had as a main priority the maintenance of public order. Article 75 of the decree of November 10, 1903, provided that: "Indigenous justice will apply local customs in all matters, in all that they do not contradict the principles of French civilisation". The local customs that threatened public order were suppressed.

Like what happened in Kabylia, the French military also engaged in the study of local customs and the drafting of the local customary law of West Africa. The initiative for the drafting of African customs was taken by the International Union of Law and Political Economy, which had its headquarters in Berlin in 1897. On January $3^{\text {rd }}$, 1897, Colonel Trentinian, Lieutenant-Governor of Sudan, addressed to all the Commanders of region, circles and posts, a note in which he asked to answer the questionnaire which had been sent to him by the International Union of Law and Political Economy in Berlin.

In 1905, Roume, Governor of Western Africa, claimed to the French administrators that they should avoid imposing the French laws on the indigenous African population, which were the opposite of their customary law. Nonetheless, at the same time, Roume defined the Natural law as the "source of every law ${ }^{46}$ " and claimed that the African customs which were opposed to the principle of "humanity" and the "Natural law "would not be

45 B. MaupoIL, «L'étude des Coutumes juridiques de l'A.O.F », in Coutumiers Juridiques de l'Afrique Occidentale Française, Tome I, Sénégal, Paris, 1939, p. 1.

46 E. LE Roy, Mamadou WANE, "La formation des droits non étatiques », in Encyclopédie juridique de l'Afrique Vol. I (1982), Abidjan, Dakar, Lomé, Les Nouvelles Editions Africaines, 1982, p. 366. 
tolerated ${ }^{47}$. Like what happened in Algeria, the Customs of the indigenous populations of West Africa had been codified in 1939 in a three volumes work titled Les Coutumiers juridiques de l'Afrique de l'Ouest and customs of the West Africa populations were classified through the French legal tradition categories.

\section{The reformation of the Muslim law and the customary law}

At the beginning of the $20^{\text {th }}$ century, the French colonial political theory was crossed by two schools of thought. The first one was that of the assimilationists, who claimed the necessity of the legal acculturation of the French colonies' indigenous populations through a gradual replacement of the local legal tradition by the French law. The assimilationists argued the necessity of reforming some customs using the argument of the natural law. This way of thinking was the dominant one in Algeria until the beginning of the $20^{\text {th }}$ century.

The second School of thought was represented by the supporters of the policy of association, which were critical towards the legal assimilation and the legal acculturation of the indigenous populations in the French colonies. The association policy inspired the French administration of the French protectorate in Tunisia, Morocco and Indochina. The association policy advocated the necessity of a break with the colonial policy adopted by the French in Algeria and supported the necessity of undirected rules policy based on the maintenance of the local political institutions and the local customary laws.

47 Ibid.. 
The associationists were very critical towards the notion of natural law, like the philosophy of the enlightenment era and the ideology of human rights developed during the French revolution. Vignon, who was one of the most representative supporters of the policy of association, criticised the assimilationist policy that France used in Algeria, qualifying it as "sentimentalist" and, at the same time, the cult of the reason and the natural law. More precisely, he criticised the approach of the French judges in Algeria for reforming the Muslim law in the name of the principle of the natural law ${ }^{48}$.

At the beginning of the $2 \mathrm{O}^{\text {th }}$ century, some French deputies, as Marchal and Clémentel, claimed the necessity for France to break with the assimilationist policy in the colonies ${ }^{49}$. This idea dominated the congress of the colonial sociology of $1900^{50}$. The dominant idea was that, in Algeria and in the other French colonies and protectorates, the assimilation was possible only with the non-French European immigrants and the Jews. Such an idea was supported by Octave Depont, who claimed that legal assimilation was possible only with European populations ${ }^{51}$.

The assimilation adopted by the French in Algeria was criticised by the scholars of the School of social peace (École de la paix sociale) too. They were the scholars of the French engineer and sociologist Pierre Fréderic Le Play. However, and differently from the other associationists, the scholars of Le Play did not cruise to the idea of natural law itself, but only to the universalist

48 P. Vignon, Un programme de Politique Coloniale. Les Questions Indigènes, Paris. Librairie Plon, 1919, p. 361.

49 O. Le cour Grandmaison, La République impériale. Politique et racisme d'état, Fayard, 2009, p. 108.

$5^{\circ}$ Ibid., p. 118.

${ }^{51}$ O. DePont, L'Algérie du centenaire, Paris, Sirey, 1928, p. 44. 
lecture developed during the French Revolution about this concept. The School of social peace had a very conservative vision of law, critical to codification and claiming that the law should be rooted in the customary law and the natural law. As explained by Guerlain, the scholars of Le Play created a synthesis of the German historical school approaches and the modern natural law ${ }^{52}$. As said above, the members of the colonial approach of the Social Peace school were anti-assimilationist but, contrarily to other associationists like Marchal Clémentel, they did not despise the customary law of the indigenous populations of the French colonies. For them, France needed to maintain the indigenous populations' customary law and, consequently, they criticised the French policy in Algeria. They gave a favourable judgment to the French policy in Tunisia and Indochina where, contrarily to what happened in Algeria, the local political institutions had not been weakened.

The French policy in Algeria was partially assimilationist. After 1871, with the fall of Napoleon III's Regime, the military regime adopted in Algeria was replaced by a civil one. The new policy of this regime was more assimilationist than that of the precedent military regime. Even though the French authorities denied the majority of the rights to French citizenship, Algeria's Muslim population was submitted to French law after the adoption of the decree of August $29^{\text {th }}, 1874^{53}$. The only exception was the case of

\footnotetext{
$5^{2}$ L. GUERLAIN, Droit et société au XIXe siècle. Les leplaysiens et les sources du droit (18811914), PhD thesis, Université Montesquieu, Bordeaux IV, 2011, p. 263.

53 The Algerian Jewish were totally assimilated after the adoption of the Crémieux decree in 1870. The rest of indigenous Muslim population was considered as French subjects but not French citizens. So, they could not enjoy the political rights, but at the same time until they
} 
disputes in the matters of Family Law and private properties in the specific case where all the parties were Muslim. Such cases were submitted to the Muslim law and the Kabyles' customary law.

The natural law was a concept used by the assimilationist liberal colonial theory supporters, as Le Roy Beaulieu and Besson. These two authors wrote treatises on the way that the French should rule their colonies.

Le Roy Beaulieu was inspired by the liberal theories of the physiocrats, who were attached to the natural law. His work titled The colonisation of the modern people criticised how France colonised during the Ancient Regime and claimed that the new colonisation should respect the natural law ${ }^{54}$. For Le Roy Beaulieu, the indigenous populations' cultural acculturation was compliant with Natural law principles because "all societies should be equal" and, consequently, "the younger society isn't be sacrificed to the elder one ${ }^{55}$. But at the same time Le Roy Beaulieu claimed the necessity of the legal acculturation of the indigenous population of Algeria in view of a future legal assimilation of the entire Muslim population of Algeria. This acculturation was to be accomplished through a gradual reform of the Muslim law and the local customs and with the Civil Code, private property and monogamy.

Besson was a jurist who advocates the necessity of a legal reform of the customs of the Algerian indigenous, given their legal acculturation. About this point, he explicitly claimed that France should be "sparing to reform [...] the political and social constitution of our Algerian subjects ${ }^{56 “ . ~ H o w e v e r, ~ B e s s o n ~}$

were not naturalised, they could be ruled in the matter of personal status and family law by the Muslim laws and the Kabyle's customary law.

54 M. Paul Leroy-Beaulieu, op. cit., p. 27.

55 Ibid, p. XIII.

${ }^{56}$ E. BESSON, op. cit., p. 341. 
criticised the phenomena of the codification of Muslim law and the customary law. This operation was risky because it could officialise Muslim and customary rules, which were opposed to the principle of natural law ${ }^{57}$.

According to Besson, the Muslim and the customary law should be reformed by the French judges through an interpretation of that norm under the light of the natural law principles ${ }^{58}$. So, the jurisprudence was perceived as the best way for reforming the Muslim law and the Kabyles' customary law.

This idea was shared by the Law University chairman, Robert Estoublon, who claimed that the Muslim should be conciliated with the French law through Natural law and a common morality ${ }^{59}$.

At the end of the $19^{\text {th }}$ century and until the beginning of the $20^{\text {th }}$ century, some French judges advocated the idea of the legal assimilation of the Kabyle population and consequently the replacement of the Kabyle customs that were opposite to the French law by the latter. The natural law was frequently an argument used to legitimise the reform of the customs, which were opposite to the French Law principles and the Natural law. The natural law was identified with the French law, or this notion was sometimes synonymous with public order (ordre public). So, the French court made a rhetorical use of the notion of natural law as an argument for reforming the customs of the indigenous population.

57 Ibid., p. 342.

$5^{8}$ Ibid.

59 R. Estoublon, « Mariages musulmans et kabyles », in. Revue algérienne et tunisienne de législation et de jurisprudence, Alger, Adolphe Jourdan, 1892, 1ère partie, p. 81-91. 
This legal reformation was stronger in Kabylia due to different reasons. The first one was that after the fall of the military regime in 1870 , the local customary assembly was replaced by the French judges (juges de paix). They, after the decree of 1874 , were called to apply and interpret the kabyle customary law. After the decree of 1887 , the customary assessors were suppressed, and the only judges allowed to bring justice in Kabylia and interpret the local customs were, so, the French ones.

The second reason was the fact that kabyle customs were codified by Hanoteau and Letourneux, which made them more malleable and easily editable. Judge Gaston Ricci also shared the idea of the necessity of the reformation of the kabyle customary law through jurisprudence. He was a convinced assimilationist and claimed that the Kabyle population should be assimilated to the French culture. Such an idea was supported by the French governor Sabatier and Le Roy Beaulieu, who also defended the grant of French citizenship to the entire Kabyle population.

Judge Ricci reformed the kabyle customary law recognising to the Kabyle women the right to divorce, a right denied by the Kabyle's customs. In three cases, on January $3^{\text {rd }} 1899$, April $23^{\text {rd }} 1902$ and June $16^{\text {th }} 1902$, the French judge Gaston Ricci decided that the French law should prevail on the kabyle customary law, in the name of the French legal traditions superiority and of the natural law.

In a decision of November $18^{\text {th }}$, 1922, the Court of Appeal of Algiers decided that the customary law was revisable if opposite to the natural law ${ }^{60}$. Simultaneously, the court declared that these customs were also revisable

${ }^{60}$ Revue algérienne, tunisienne et marocaine de législation et jurisprudence, (T.38), 1923 (T. 39), p. 83 . 
because they had evolved, and the jurisprudence should follow these social changes.

The chairman of the Law University of Algiers, Éstoublon, gave a favourable judgement to this decision and claimed that the French law was inspired by the natural law, which allowed the indigenous population of Algeria to follow their customs ${ }^{61}$. However, he could not tolerate the violation made by that customs against the principles of French justice, which affect family law ${ }^{62}$.

The same jurisprudence used the argument of the natural law for recognising to the Kabyle women the right of inheritance. In the decision of the Muslim court of appeal of Algiers, the Court decided that customary was revisable when opposite to the Natural law ${ }^{63}$.

The solution adopted in Algeria was a legislative intervention. The legislator has adopted some laws and decrees that reformed the kabyle customary and the Muslim laws in the matter of family law. The decree of June $1^{\text {st }}, 1902$ reformed the kabyle customs in the matter of minors and the decree of May $10^{\text {th }} 1931$ and the decree of May $2^{\text {nd }}, 1930$ reformed the customs in the matter of engagement and marriage. The decree of May $19^{\text {th }}, 1931$, reformed the customs in the matter of divorce and heritage, recognising to the Kabyle women the right to divorce and inherit. The French legislator reformed the Algerian Musulim law in the matters of the rights of minors through the decree of July 30 $0^{\text {th }}, 1957$ and the Ordinance n. 59-274 of 1959.

${ }^{61}$ Revue algérienne et tunisienne de la législation et de jurisprudence, Tome VIII, 1892, p. 81. 62 Ibid.

63 Journal de la jurisprudence de la cour d'appel d'Alger et de la législation algérienne, p. 258. 
It is curious to notice that the administrators who ruled the French colonies in West Africa and Cameroon and applied a policy of association started during the $2 \mathrm{O}^{\text {th }}$ century an operation of reformating the customs there. Even though most governors advocated the policy of association, this reformation had not been applied only to the rites and customs that were dangerous for the public order, such as the ritual crimes ${ }^{64}$. It also affected the customs that ruled the traditional African family law, like marriage and dowry ${ }^{65}$.

\section{Conclusion}

Despite the fact that the Modern law theory appeared in France only during the $17^{\text {th }}$ century, the notion of natural law played an important role during the French colonial Empire. The natural law was a rhetorical tool used to conciliate two contradictory objectives of the French republican colonisation, namely the economic exploitation of the colonies and at the same time the exportation of the ideology of the human rights developed in France during the French revolution, a period in which the natural law theory was strictly attached to the concept of the Human rights. As we saw, the colonial use of the notion of natural law is due to the degradation and impairment of this notion during the last years of the French Revolution. Such

\footnotetext{
64 That was the case of the decrees of April 26 $6^{\text {th }}, 1923$ which repressed the anthropophagical crimes in West African French territories and Cameroon, and the decree of May 28 ${ }^{\text {th }}, 1927$ which repressed the preparation of the poisons.

65 The decree Mandel fixed the legal age at 14 years old and imposed the consent in the marriage. The decree Jacquinot of 14 September 1951 reformed the customs of the dowry
} 
an impairment was due to the incompatibility between the application of human rights and the interest of the colonial lobby, which had an interest in the slave trades in the French colonies. Therefore, the natural law that was an instrument of extension of human rights during the French revolution became an instrument of colonial domination and acculturation after the Egypt Campaign and the Algerian conquest.

This instrumental use of the notion of natural law for the colonial purpose appeared first during the Campaign of Egypt and was later applied in Senegal and Algeria after 1830. However, Algeria was a laboratory for the French colonial law of the $19^{\text {th }}$ and $20^{\text {th }}$ century. In Algeria, the modern natural law theories inspired the colonial legislation about private property, as the choice of codification of the Muslim law and the Kabyle's customary law and finally as an argument by the assimilationist judges who wanted to reform the Kabyle's customary law in the matter of women and minors' rights. However, the anti-assimilationist members of the School of Social Peace used the argument of the natural law as a shield for protecting the customs of the indigenous population against legal acculturation. We also saw that in the French colonies of West Africa, where the colonial law was applied as undirected rule policy, the notion of the natural law was used for the repression of those customs, which represented a danger for the public order.

We can conclude that the notion of natural law played an important role in French colonial law after the $19^{\text {th }}$ century. However, this role was instrumental for the local population's legal acculturation and the maintenance of order in the colonies. 


\section{References}

Amselle J-L., Vers un multiculturalisme français, Champs, Flammarion, Paris, 1996

E. Besson, «La législation civile de l'Algérie », Edition Chevalier Marescq, 1894

Bontems C., "Coutume kabyle, jurisprudence et statut féminin », in $L a$ coutume-Custom, Troisième partie, Europe orientale, Asie et IslamEastern Europe, Asia and Islam, Recueils de la Société Jean Bodin, Bruxelles, De Boeck Université, 1992, (pp. 245-268) ; " La coutume kabyle et l'implantation des systèmes étrangers», In La réception des systèmes juridiques: implantation et destin: textes présentés au premier colloque international du Centre international de la Common law en français (CICLEF) / sous la direction de Michel Doucet et Jacques Vanderlinden, pp. 78-101 ; «L'invention du droit musulman algérien à l'époque coloniale (XIX siècle). Une approche anthropologique », in Le débat juridique au Maghreb (sous la dir. A. Mahiou), Publisud, Iremam, 2009, pp. 39-51; «La découverte de l'anthropologie juridique. Un témoignage », in Cahiers d'Anthropologie du droit, Droit et cultures, Anthropologie et droit. Intersections et confrontations, 2004, Karthala, pp. 73-85

Carrey E.., Récits de Kabylie. La conquête de 1857,1858, 2-ème édition, Alger 2007, Alger

Condorcet N. de, Réflections sur l'esclavage des nègres, Neufchatel, 1781. Deroussin D., « Pothier, la coutume (d'Orléans) et le droit coutumier », in

F.Garnier, G. Cazals, Les décisionnaires et le coutume, Contribution à la fabrique de la norme, Toulouse, $\mathrm{P}: \mathrm{U}$ : Toulouse 1, 2018, 
Estoublon R., « Mariages musulmans et kabyles », in. Revue algérienne et tunisienne de législation et de jurisprudence, Alger, Adolphe Jourdan, 1892, 1ère partie

Ferry J., «Premier rapport de M. Didier au nom de la commission de l'Assemblée législative », 9 juillet 1851, in E. Robe, 1854,

Ghabrial S., Le 'fiqh francisé'?: Muslim personal status law reform and women's litigation in colonial Algeria (1870-1930), P.H.D. thesis, McGill's, 2014.

Hanoteau A., Letourneux A., La Kabylie et les coutumes kabyles, Imprimerie impérial, trois vol., Paris, 1873

Leroy-Beaulieu M.P., De la colonisation chez les peuples modernes, Paris, Guillaumin Libraires, 1874

Le Roy E., « La Coutumes et la réception des droits romanistes en Afrique noire", in Recueils de la société Jean Bodin pour l'histoire comparative des institutions, La coutume, volume 51-1990, Bruxelles, De Boeck-Wesmael, 1990

Le Roy E., Mamadou Wane, «La formation des droits non étatiques », in Encyclopédie juridique de l'Afrique Vol. I (1982) , Abidjan, Dakar, Lomé, Les Nouvelles Editions Africaines, 1982

Maupoil B., «L'étude des Coutumes juridiques de l'A.O.F », in Coutumiers Juridiques de l'Afrique Occidentale Française, Tome I, Sénégal, Paris, 1939

Mari (de) E., «Des devoirs du concessionnaire aux droits du propriétaire : le cas de Saint-Domingue (XVIIe-XVIII siècle) », in L'empire de la propriété. L’impact environnemental de la norme en milieu contraint. Exemple de droit colonial et analogies contemporaines, 
Sous la direction de E. de Mari et D. Taurisson-Mouret, préface de Thierry Revet, Paris, Victoire Editions, 2016,

F. Gauthier, Triomphe et mort du droit naturel en Révolution 1785-17951802, Pratiques Théorique, Paris, Puf, 1992

Le cour Grandmaison O., La République impériale. Politique et racisme d'état, Fayard, 2009

Mercier E., La propriété foncière chez les musulmans d'Algérie, Paris, Ernest Leroux éditeur, 1891

Mirabeau (V. Riqueti, marquis de), Quesnay F., Philosophie rurale ou Economie générale et politique de l'Agriculture, Les Libraires associés, Amsterdam, 1763

Mirabeau (V. Riqueti, marquis de), L'ami des Hommes, 6 vol., Avignon, 17561760.

Montesquieu Charles de Secondat-Baron de La Brède, De l'esprit des lois, tome I, Garnier Frères, Paris, 1961

Portalis J-É., Discours préliminaire du premier projet de Code civil, Préface de Michel Massenet, Collection «Voie de la cité», Editions confluences, Bordeaux, 2004

Pothier R.-J., Traité des personnes et des choses, in De M. Dupin, Euvres de Pothier contenant les traités du droit français, Paris, Pichon-Becher, 1827

Pothier R.J., Traité sur différentes matières de droit civil, appliquées à l'usage du Barreau et de la jurisprudence française, tome 4, Paris, Orléans, Jean Debure/Veuve Rouzeau-Montaut, 1774,

Tourme-Jouannet E., « Des origines coloniales du droit international », in The Roots of International Law. Les fondements du droit international, Leiden, Boston, Nijhoff publishers, 2014 
Vignon P., Un programme de Politique Coloniale. Les Questions Indigènes, Paris. Librairie Plon, 1919

Volney C.-F. de Chassebœuf, Les Ruines ou Méditation sur les révolutions des empires (1791), présentation de J. Thulard, Paris-Genève, Slatkine,1979. 